\title{
The Kazan Period in the Life of the Historian V.M. Khvostov
}

\author{
Albina Imamutdinova ${ }^{1}$ \\ Nikita Kuvshinov ${ }^{2}$ \\ Elena Venidiktova ${ }^{1}$ \\ Anfisa Ibragimova ${ }^{1}$ \\ ${ }^{1}$ Kazan Federal University \\ ${ }^{2}$ Kazan State Power Engineering University
}

Doi: 10.36941/jesr-2019-0029

\begin{abstract}
Vladimir Mikhailovich Khvostov is one of the famous, thoroughly educated Russian historians. In his scientific heritage are widely represented lots of works on the history of diplomacy and international relations, on the study of major problems of General and national history. He himself defined that the most important secret of his life was his childhood and the inspiration for the poetry of the "Prophet", the poem of Alexander Pushkin, the father of modern Russian literature. This poem was the most unusual incident in a highly Christian society two centuries ago, with its poet, the most unusual figure among the elite and the aristocracy. Poetry and poetry presented a transformative image of the Prophet that did not conform to the official description of the Gospel and the Torah, but rather resembled the Muslim definitions of their Prophet. The poem became the symbol of one of the greatest Russian intellectuals to rebel against the rule of the Church-Torah system in European societies, and as a result Pushkin was even excommunicated by the Council of Bishops of the Orthodox Church, but escaped the deadly tsarist reign of his youth.Among them are the doctoral dissertation "Foreign policy of the German Empire in the last years of the chancellorship of Bismarck", articles on the history of international relations in the middle East in the late XIX century, the manuscript of the 2nd volume "History of diplomacy", the introduction to the book "History of foreign policy of the USSR", numerous articles and reports on various issues of foreign policy of the USSR and international relations. Article is devoted to the famous historian, scientist and public figure academician Vladimir Mikhaylovich Hvostov, describes his educational experience on the basis of archive documents. The research also covers Vladimir Mikhaylovich Hvostov's early professional development. Further development of his life should be continued through detailed studying the personal fund of V.M. Hvostov which is located in Russian Academy of Science Archive.
\end{abstract}

Keywords: History, Historiography, Pedagogics, Upbringing, Development, Education, Kazan university

\section{Introduction}

Kazan is an industrial, commercial and cultural center on the European and Asian borders and is the most important cultural city for the Tatars. The original town was at the Kazan site of Kerman, which is said to be built on a pot-like hill, and the word "Kazan" in the Tatar language means pot. The people of Kazan are mainly Russians and Tatars, with Tatars $2 \%$ and Russians $2 \%$, other ethnicities such as the Chawash (Turkic and close to Tatars), Azerbaijanis, Ukrainians and Jews. Both Russian and Tatar languages are official in the Republic of Tatarstan. The language of Russians and mediators is Russian, and most of the Tatars are bilingual. About one-third of 
marriages in Kazan are mixed marriages between Russians and Tatar

Kazan has been affiliated with the university since the 5th and has been the largest mosque in Russia (and possibly Europe) since the name of Qalarif Mosque. In year 3, Kazan celebrated its millennium.

An important role to the personal development of Vladimir Mikhaylovich Hvostov belongs to his family (Archive of the Russian Academy of Science). Vladimir Mikhaylovich's grandfather, Mikhail Nikiforovich, has graduated from the law Faculty of Moscow University in 1862, since then he worked as a teacher of history and geography for two years in Mariinsky school in Kazan, after that he worked as the companion of the prosecutor in the Simferopol district court. After his death the upbringing of children has fallen upon the grandmother of Vladimir Mikhaylovich - Maria Kirillovna.

\section{Methods}

General and special-historical methods are the main for research (Khvostov, 1969).

The historical-genetic method has allowed to recreate a creative portrait of Vladimir Hvostov in chronological framework of the studied period - the XX century (the 1930-1970th); the historicalcomparative method was applied to the identification of innovation made by V.M. Hvostov in study of national and general history ; also chronological, historical and biographic methods, techniques of the historiographic and source study analysis have been used.

The principle of historicism and objectivity to assess the contribution of V.M. Hvostov to study of Russian and USSR foreign policy history and the international relations, in teaching social sciences, in activity of pedagogical sciences Academy during the considered period became the basic principles of a research.

\section{Results}

Seldom happens that the scientist in his first work successfully defends the main idea and approach of his future activity as it was made by Vladimir Mikhaylovich Hvostov. The dissertation became his first published work. Perhaps, young - he was only 21 when he graduated of the Eastern teacher training institute he hasn't planed routes in life. Anyway in the name of his first work we can trace the further way of V.M. Hvostov's science and public researches. History, modernity, school. History in the indissoluble communication with the present. The way from regular history towards the pedagogical science (ARAC, 1667).

It should be noted that initially Vladimir Mikhaylovich has entered Kazan university Mathematical department, at Physics- mathematical faculty. In Vladimir Mikhaylovich Hvostov's personal record from Kazan federal university archive there is a note concerning the admission to testing for transfer in number of students of above-mentioned faculty and also a record of July 27 , 1923 with at the following request of documents issue for transfer to another university has remained. He writes in one of his autobiographies that he was transferred into Eastern teacher training institute to History-economical department, after a year of study at Mathematical department (ARAC, 1604). That was the first independent step on his own way of professional activity. Studying at Eastern teacher training institute Vladimir Mikhaylovich had taken the following courses and had executed a practical trainings in the following directions:

A. Theoretical courses: bases of social labor education. General course of psychology. Biology. Anatomy and human physiology. State law of the USSR. Political economy. Economic geography. History of ancient art. Russian history (2 parts). Primitive culture. Historical materialism. French Revolution. French. Tatar. Social science technique (2 parts). Modern history.

B. Practical training: Political economy. History of world war (in memoirs of contemporaries). History of ancient art. Russian history. Economic policy of the Soviet power. History of Allunion communist party. Historical materialism. History of medieval culture. State law of the USSR. French revolution. Pedagogical practical work. Social science technique. Summer work practice. 
It is remarkable that his report from seminar of materialistic history "The Russian imperialism in Pokrovsky's understanding (from the point of view of dialectics to history questions)" has remained in Russian Academy of Sciences Archive. A work task - clarification of Pokrovsky's views on an imperialism, the dialectician of his concept. Vladimir Mikhaylovich writes that he agrees with Pokrovsky, considers his views on an imperialism are more dialectic, than the Pavlov's theory of an imperialism (ARAC).

During training in higher education institution Vladimir Mikhaylovich has showed his accuracy and discipline. For that reasons teachers respected him. During his stay in institute he worked in Committee for history of Great October revolution in1923-1924 and also at workers' faculty of Kazan university in 1924-1925.

As a student, V.M. Hvostov worked as the laboratory assistant in social science office of workers' faculty at Eastern teacher training institute (since October 1, 1925 till February 1, 1926), then he was accepted as an assistant to the Department of western revolutionary history movements' in the Tatar communistic university since January 15, 1926.

In 1926 Vladimir Mikhaylovich Hvostov moved to Moscow and came to a postgraduate education at Institute of history of the Russian association of research institutes of social sciences which he successfully graduated in 1929 .

\section{Summary}

Pedagogical and administrative activity of the scientist is extensive and comprehensively. Vladimir Hvostov taught at K. Liebknecht Industrial teacher training institute, Smolensk teacher training institute, Moscow institute of history, Moscow state university. V.M. Hvostov was a manager of the sector at department of the Central Committee of the All-Union Communist Party (bolsheviks), the director of the Higher diplomatic school, the chief of Archival management of the Ministry of Foreign Affairs of the USSR, the member of Board of the Ministry of Foreign Affairs of the USSR, the responsible consultant of department of the Central Committee of Soviet Union Communist Party, the director of Institute of History at Sciences Academy of USSR, the president of Pedagogical Sciences Academy of USSR.

\section{Conclusion}

Further development of this subject should be continued through detailed studying the personal fund of V.M. Hvostov which is located in Russian Academy of Science Archive. This archive is created by V.M. Hvostov's widow - Y.F. Stroiteleva and his daughter - K.V. Hvostova in 1973. It consists of 544 paperwork for 1901-1975. The repository which directly concerns his pedagogical activity had been studied. The questions connected with public work of the scientist and publisher work as soon as analysis of contribution belong to Vladimir Mikhaylovich Hvostov about international relations history, correlation of his views with current researches of history and diplomacy, world wars, questions of foreign policy from the point of view of modern approaches with their pluses and minuses can become continuation of this research.

The majority of the materials which are available in fund are connected with Vladimir Mikhaylovich's activity in Academy of Pedagogical Sciences of USSR, pedagogical and public work. The important place in materials are belong to V.M. Hvostov's reviews of works and scientific activity of various persons, doctoral and master's theses and also the review of books by contemporaries (Hvostov, 2006; Zemsky et al., 1957; Deeva et al., 1958).

Particular interest of his life and experience is provided by documents about V.M. Hvostov's participation in international congresses works, conferences and scientific organizations. Documents on V.M. Hvostov are stored in fund (29 cases for 1926 - 1974). They consist of N.M. Druzhinin, M.V. Nechkina, I.I. Mintz, A.L. Sidorov, M.N. Pokrovsky, S.D. Skazkin, E.V. Tarle's reviews, both newspaper and journal materials about his performances.

Great role in study of V.M. Hvostov's life and activity belongs to his correspondence. We already found the most significant and he most known of his contacts among his addressees and correspondents: L. Bolts, A.A. Gromyko, N.M. Druzhinin, A.S. Erusalimsky, I.M. Maysky, A.3. 
Manfred, I.I. Mintz, V.P. Potemkin, S.D. Skazkin, V.V. Struva, M.N. Tikhomirov, W. Ulbricht, L. Stern.

\section{Acknowledgements}

The work is performed according to the Russian Government Program of Competitive Growth at Kazan Federal University.

\section{References}

ARAC, f. (1604). op. 4, folder. 226. -20 p.

$A R A C$, f. (1604). op. 4 , folder. 826. -39 p.

$A R A C$, f. (1667). op. 1, folder. 336. -92 p.

ARAC, f. 693, op. 4, folder. 646. -19 p.

Archive of the Russian Academy of Science, f. 693, op. 4, folder. 57. - 7 p.

Deeva, G. K., Zhukova, E. M., Sivolobova, M. A., \& Khvostov, V. M. (Eds.) (1958). Documents of Foreign Policy of the USSR. T. 2. - M.: State publishing house polit. lit-ry,. $-804 \mathrm{p}$.

Hvostov, V. M. (2006). 100th anniversary of academician. Recent and Modern History, 1, 247-250p.

Khvostov, V. M. (Ed.) (1953). A Textbook on Modern History (1870 - 1918).- M.: State. educational-PED. publishing house of the Ministry of education of the RSFSR,. $-244 \mathrm{p}$.

Khvostov, V. M. (Ed.) (1969). Yearbook of German History. - Moscow: Science, - 462 p.

Zemsky, I. N., Mayorova, S. M., Sadchikov, I. V., \& Khvostov. V. M. (Eds.) (1957). Documents of Foreign Policy of the USSR. T. 1. M.: State publishing house polit. lit-ry,. $-772 \mathrm{p}$. 